\title{
Continuing Theological TRAining AT THE University of Pretoria
}

Author:

Malan $\mathrm{Nel}^{1}$

\section{Affiliation:}

${ }^{1}$ Centre for Contextual

Ministry, University of

Pretoria, South Africa

\section{Correspondence to:}

Malan Ne

e-mail:

malan.nel@up.ac.za

Postal address:

PO Box 12549, Gauteng,

0028, South Africa

\section{Keywords:}

theological training;

Faculty of Theology;

University of Pretoria; continuing professional development; Dutch

Reformed Church

\section{Dates:}

Received: 16 Feb. 2009

Accepted: 07 Sept. 2009

Published: 17 Dec. 2009

How to cite this article: Nel., M., 2009, 'Continuing theological training at the University of Pretoria', Verbum et Ecclesia 30(3), Art \#130, 7 pages. DOI: 10.4102/ ve.v30i3.130

\section{This article is available} at:

http://www.ve.org.za
(C) 2009. The Authors. Licensee: OpenJournals Publishing. This work is licensed under the Creative Commons Attribution License.

\section{INTRODUCTION}

Lifelong learning is a term that is currently much in vogue. Ward states:

You find the term 'lifelong learning' all over the place in today's culture, and not just on the notice boards in institutions of further and higher education, in literature on continuing professional education or in books on study skills. Tap the words on an internet search engine and you will gain access to over four million sites.

(Ward 2005:1)

The University of Pretoria (UP) is probably one of only a few universities in South Africa with its own centre for continuing education, namely the Centre for Continuing Education at the University of Pretoria (CE@UP). The Centre enables people from all walks of life and in all the disciplines being taught at UP to participate in continuing training and learning. Most professional groups would agree that continuing training is needed. In this fast-changing world, no trained person is ever trained for life. Life is a journey, as is training. One of the centres, whose programme is described below, uses the motto: 'Wie leef, leer. Wie leer, leef!' (which, freely translated, means: Who lives, learns. Who learns, lives!)

Mark Rouch (2000:19) tells of his pastor's involvement as far back as 1940 in a summer school at Union Theological Seminary, New York City. Only in 1960 did Gamble publish his book on the Continuing theological education of the American minister. The book, as well as a doctoral study on the topic (Trost 1962), ${ }_{1}^{1}$ prompted the National Council of Churches in the United States to establish a standing committee on Continuing Education (see Rouch 2000:20) in 1964. The move led to the establishment of the Society for the Advancement of Continuing Education for Ministry (SACEM). In the Roman Catholic Church in the United States, a similar development has taken place since 1972 (Rouch 2000:24-26). The Lutheran Church in America also developed similar structures. The Division for Professional Leadership and other bodies constitutes the Continuing Education Committee. ${ }^{2}$

Such developments led to denominational involvement. Seminaries also introduced such programmes as the well-known DMin degree. A number of associations were formed, in which independent organisations became involved (see Rouch 2000:28-33). The Center of Continuing Education at Princeton Theological Seminary, with which the Centre for Contextual Ministry (CCM) at UP has been associated for the last nine years, was already established in 1960.

The issue continues to be found on the agenda of many churches in many different countries. The British Journal of Theological Education, which was renamed the Journal of Adult Theological Education: JATE in 2004, has been published since 1987. The journal, which is published by the Association of Centres of Adult Theological Education, aims to

provide a forum for articles and reviews concerning the theological education of both ministers and laity, whether in colleges and universities, by distance learning programmes, or within regional and local church structures.

\section{(British Journal of Theological Education 1992:1)}

The invaluable contribution made by the Church of England to the integration of ministerial education is also noteworthy. The report builds on two decades in which continuing ministerial education played 'an increasingly significant role in building up and supporting the professional life of clergy' (Archbishops' Council 2001:Preface). As in many other developments, the ultimate goal is to provide ministerial development in different phases 'from selection, initial training, into the first four years and then into ministry-long CME' (Archbishops' Council 2001:2). The UK-based research described by Withnall (1986) is based on a broad ecumenical approach. The chapter on 'the psychology of adult learning' (Withnall 1986:23-26) laid part of the groundwork for the practice of continuing education, especially in the case of the continuing theological training of pastors (see also Aspin 2007). In the

1.Another DMin dissertation was written by Wagener on the topic, while he was studying at Princeton Theological Seminary in 1982

2.A good example of the approach and material produced by the Council for Lutheran Theological Education can be seen in their Spring 1982. Guide to continuing education programmes for professional leaders. 
implementation of the A-Z policy (discussed below) in the Dutch Reformed Church (DRC), the National Forum for Continuing Ministry Development has expounded similar guidelines and values for training adults (Bybel-Media 2007).

Due to the many similarities with the developments in South Africa (at least in the DRC and through the work of the CCM, as discussed below), the move towards the professional development of the ministry should be considered (see Nel 2001 2002:151-167, 2004:584-618, 2005:459-506 for a more in-depth discussion of the issue of the professionalisation of the ministry). Following on a publication by James Glasse (1968), Rouch (1974) published a work on competent ministry and related continuing education, in which he defines continuing education as:

An individual's personally designed learning program which begins when formal education ends and continues throughout a career and beyond. An unfolding process, it links together study and reflection and participation in organized group events.

(Rouch 1974:16-17)

Rouch (2000:35) also describes how, 'as focus on profession waned, a new emphasis on spirituality in ministry began to emerge'. Such a description ties in with worldwide developments. There is an urgent need for the spiritual development of pastors, alongside their initial and continuing training. Trost (1962:1) stated, as the reason for his research, that he wished to encourage 'the further development and expansion of programs designed to increase the minister's scholarly and professional competence'. Spirituality is an inextricable part of such competence. The research undertaken by Sevier (2002) proves beyond any doubt that pastors are not only professionally challenged, but also under stress, as regards their competency. In addition to investigating a number of different sources, she interviewed a great many pastors around the country and in different settings. She also worked with Bruesehoff (2000), who co-authored another Alban Institute study on Clergy renewal. She argues (2002:8) for spiritual renewal, due to, among other reasons, pastors experiencing stress at work, of whom $12 \%$ experience stress on a daily basis, $18 \%$ on several days each week, and $40 \%$ once or twice a week. She argues that there is a strong relationship between the spiritual renewal of the pastor and the rejuvenation or revitalisation of the local congregation, which is a topic that is currently under discussion in the DRC. As a result, each pastor should be able to take a paid sabbatical on a regular basis. The congregations concerned can only benefit from such a provision. The important connection between continuing theological education and ministerial development demands urgent consideration by churches in South Africa. Oehler (2000:237) calls being open to such a connection 'welcoming the whole person' in terms of continuing theological training and programmes.

Lifelong learning is of relevance to Christians. Andreas Ledl's (2007) book is the result of her dissertation on Eine Theologie des Lebenslangen Lernens: Studien zum pädagogischen Epochenwandel bei Luther. She describes the contribution made by two 'nahezu unbekannter Reformatorender "zweiten Generation"'(Ledl 2007:9), namely Hieronymus Weller and Christoph Fisher, who played a 'nebenrolle' (Ledl 2007:11) in the Reformation. Weller describes the situation best in terms of Psalm 119: 'Wir haben daran zu lernen weil wir leben und können's dennoch nimmer mehr auslernen.' In the light of this introduction: lifelong learning is on everybody's plate.

\section{CONTINUING TRAINING AT THE FACULTY OF THEOLOGY, UP}

\section{How it all started}

Already in 1978 the DRC decided that continuing theological training should be compulsory for all those pastors in ministry within the denomination (NGK 1978:650,916). The taking of such a decision, among other reasons, prompted the Faculty of Theology to put the necessary training in place. Prof. A.J.
Smuts submitted a report in which he argued for the necessity and importance of what he called 'in-service training' (Kotze 1988:79). In 1981, the Faculty Board commissioned two of its lecturers to conduct research into what other faculties and churches around the world were doing in this regard. Both Profs A.B. du Toit and M. Nel, while on sabbatical, visited the faculties of Theology and the denominational offices in Germany and the United States as part of their research. On their report back to the Faculty Board, a new vision for continuing training was born. Their recommendations regarding the implementation of a needs assessment among pastors to determine their continuing training needs were accepted. A team of three was appointed, consisting of Profs A.B. du Toit, W. Vosloo and M. Nel. In close cooperation with Prof. Pottas (from the Department of Human Resources at UP), a questionnaire was developed. Once the necessary outcomes had been identified, a report was presented to the Faculty Board in 1983. In consultation with the two Synods of the DRC in the Northern Transvaal and Southern Transvaal of the time, the Centre for Continuing Theological Training (Sentrum vir Voortgesette Teologiese Opleiding: SEVTO) was established in 1983, of which Prof. M. Nel was appointed the first part-time director (Kotze 1988:79) ${ }^{3}$.

The Centre was established as the Centre of the Faculty of Theology, which, at the time, was considered to be the Faculty of the DRC (Division B, as distinguished from the Faculty of the other Afrikaans-speaking Church, Division A). The regulations by which UP instituted the Centre made provision for an Advisory Board, on which the DRC and the Faculty itself were well represented (Unpublished regulations, SEVTO 1984).

\section{The courses first offered}

The needs assessment among a random sample of pastors in the two mentioned synods of the DRC indicated that the primary need was for training in 'Gemeentebou' (Building up the Local Church), preaching and pastoral care. Thereafter came the need to understand the Bible. The director took the lead in developing three courses, one in each of the three fields within the Department of Practical Theology, which met with the approval of the whole Faculty.

The three abovementioned courses were already offered in 1984 The outcome of the research undertaken among the pastors also showed that the needs that they expressed depended on how long they had been in the ministry. In accordance with such a finding, it was decided to divide the pastors into groups, according to the number of years that they had spent in the ministry. The first courses were offered as follows:

- 1 to 3 years in the ministry: Preaching: course leader, Prof A.C. Barnard;

- 4 to 15 years in the ministry: Pastoral Care: course leader, Prof. A.J. Smuts; and

- $15+$ years in the ministry: Building up of the Local Church (Gemeentebou), course leader Prof. M. Nel.

A number of colleagues in the Faculty, as well as pastors in the ministry, shared in offering the courses from the start. The courses were offered over three weeks of contact teaching, from a Monday to a Friday, the first of which took place at the beginning of the year, the second in the middle of the year and the third in November. Those pastors who succeeded in their written assignments were awarded a University certificate, signed by the Dean of the Faculty and the Director of the Centre.

The Centre also developed a course in understanding the Bible for members of DRC congregations, as well as for any other persons interested in such a course. The course, which was marketed under the title 'Die Bybel en sy Boodskap' (The Bible and its Message), was offered in four semester modules, which covered the Old and New testaments in two years. Old and New

3.Since then, three other Centres have been established: BUVTO and Communitas (both at the University of Stellenbosch), and Shepherd (at the University of the Free State) 
testament scholars in the Faculty, as well as others in the local church ministry, taught the course, meaning that the Faculty had its own Bible School. Attendance was between 112 and 176 students in each semester (Kotze 1988:79). Providing continuing education for members is high on the agenda of other churches, too. In the United States, the General Assembly in 1994 took decisions based on a report that it accepted, in terms of which it recommitted itself to research and to the development of programmes that would adhere to the Church's commitment to:

Enable and affirm the conviction that all believers are called to be ministers and interpreters of God's will, and thus, are charged with the responsibility and opportunity to serve as informed and educated disciples who are prepared for evangelism, leadership, and service.

(Presbyterian Church USA 1995:59)

The Centre also offered a few courses on contemporary issues. starting, in 1985, with a course on the language of the Bible and the preacher, in 1986 another course was introduced on church unity.

The Faculty realised that pastors could earn academic credits by means of succeeding in such courses. On the Faculty succeeding in an application to offer a Master's in Practical Theology, several pastors registered for the course. The Faculty was able to offer the course in place of the exams of a major in Practical Theology in the DD degree programme.

\section{A new director: The next phase}

After Prof. Nel took up a position at Vista University, Prof. Wil Vosloo was appointed as the next director in 1989. In his unpublished memoirs, Prof. Vosloo refers to his time as director as the 'most important time of his life'. He determined to encourage the DRC and the Faculty of Theology (B) to take increased control for the Centre, so that it could become an integral part of the theological training programme.

Several other short courses and seminars were added in later years. Under Prof. Vosloo's leadership, some 12 study and/or research groups were formed, which focused on such subjects as family ministry and the liturgy. Many other shorter courses were added to the offerings, such as pastoral care for the pastor and his wife, as well as retraites on spirituality. The offerings covered a wide variety of themes. For many years about 15 courses, seminars and retraites were held each year. The largest attendance was recorded for the seminar on Satanism, which was attended by some 373 pastors and members. During the years 1991 to 1994 about 4500 people attended courses offered by the Centre (Vosloo n.d.)

In 1995 the Preaching course was offered again, as well as seminars on themes such as the Toronto Blessing (196 participants) and current songs and music (171 participants).

Prof. Vosloo also strove to make the Centre financially viable, in which he succeeded. On his retirement, the Centre had a substantial positive balance (Vosloo n.d.).

\section{THE CURRENT SITUATION}

\section{A time of reflection}

When Prof. Vosloo retired, the work of the Centre was left without a full-time director, leading to the fading away of the programme. The Curatorium, which oversaw theological training on behalf of the $\mathrm{DRC}$, eventually assembled a group of pastors for an open discussion of the issue. The formation of a task team led to the Centre for Continuing Theological Training being transformed into a 'church-owned' Centre. While SEVTO had been a University-based Centre that functioned in close cooperation with the DRC, the new Centre for Ministry Development (Sentrum vir Bedieningsontwikkeling: Excelsus) is a Centre of the DRC, which operates in close cooperation with the Faculty of Theology at UP. Initially, the Centre functioned without a formal director. Dr P.R. du Toit, who was appointed to the office of Theological Education for the DRC, took on parttime responsibility for the Centre. The members of the task team were, and still are, all full-time pastors, who cannot take any administrative responsibility for the Centre. The current situation can only be explained in full by taking two other developments into account.

The task team consisted of the following persons: Prof. D. Human (representative of the DRC lecturers), Drs K. Gerber and J. Kirkpatrick (of the Northern Synod of the DRC), Drs J. Bisschof and F. Clasen (of the Eastern Synod of the DRC), Drs T. Swart and B. van Zijl (of the Highveld Synod of the DRC) and Revs G. du Plessis and H. Retief (of the Western Transvaal), as well as Dr F. du Toit (of the Office for Theological Training of the DRC).

In an unpublished report (November 2003), the task team suggested that the Centre should focus on two main areas: the spiritual development of pastors and students, and training in leadership and leadership skills. It was then suggested that the courses should be offered in cities such as Polokwane, Potchefstroom and Nelspruit. The name Excelsus, though also suggested at the time, was not immediately acceptable to everybody.

\section{A new dispensation planned}

In 2005 Prof. M. Nel was approached by the Curatorium of the DRC to help with the reorganisation of the new Centre and its programme. He accepted an offer to pay for him to serve as Director of the CCM for 10 hours a week (NGK 2004b:6.6). Meeting with the abovementioned task team for the first time at the end of 2005, he shared with the group his vision for an annual Spring Conference to be held for pastors under the umbrella theme of Spring in Ministry and Theology (Lente in Bediening en Teologie). The two centres also agreed that all the Afrikaans courses offered by the CCM would be on offer for pastors of the DRC.

Some 270 pastors and members attended the third Spring Conference, which was held for the third time from 7 to 9 October 2008.

\section{New policy, new motivation}

The implementation of the so-called A-Z policy for pastors of the DRC, which was developed by a task team put together by the National Synod in 2005, is currently a priority. By Prof. Nel's chairing, and Dr Du Toit's membership of the task team Excelsus benefited almost immediately from the research. The A-Z policy, which builds on the research which was undertaken by Prof. Nel (see Nel 2004;2005), was officially accepted by the General Assembly in June 2007 (NGK 2007:217). The policy no longer holds with the decisions of two previous National Synods that continuing education is both 'compulsory' (NGK 1978) and 'enforceable' (NGK 2002:580). The approach that continues to be conveyed in the policy is one of motivating pastors to anticipate and appreciate their involvement in their own continuing training. The main frame of reference of the policy is the 2004 decision taken by the National Synod in 2004 in Hartenbos, namely that pastors should minister with a combination of joy and skill ('bedieningsvreugde and bedieningsvaardigheid') (NGK 2004a:165,75-176,445).

The policy is primarily aimed at recruiting and training candidates with a calling and the necessary gifts to achieve a successful ministry. Only in the second part of the policy is reference made to the sustenance of pastoral abilities and skills (see Bybel-Media 2007).

In order to achieve such sustenance, the National Forum for Continuing Ministry Development was revived. For a full year now, the Forum, with the help of many scholars (consisting of 
both academics and pastors), has developed courses on about 37 themes. The task team of Excelsus has chosen and prioritised 12 of the nationally developed courses, which will be offered at four different venues during 2010. The 12 courses will be offered over two years, in the form of three-day long sessions, in order to make the courses readily accessible to pastors (Unpublished report to the Curatorium 2008).

\section{New hope for human resources}

A final important development in the life of Excelsus is bidimensional.

In November 2007 the Curatorium decided to request greater cooperation with the CCM, by means of the Centre's incorporation of Excelsus (SBO), while allowing it to function as such, with its own coordinator. The request was approved by the Executive of the CCM on 11 August 2008. While the request was being processed, the Curatorium approached the leadership of the four Synods in the North to budget for either a full- or part-time director for Excelsus. The intention was that the director concerned would, together with Prof. Nel and the CCM, plan and develop the programme for the continuing ministryrelated development of the DRC pastors. At the same time, the connection with the CCM would allow them the ecumenical opportunities that they desired. On 12 September 2008 the Committee of the four Synods in the North decided to fund the finding of a part-time director/coordinator for the programme. Since Dr F.J. Clasen was appointed part-time to the position, he has directed the development of new initiatives, as well as that of a new agreement with the Centre.

\section{A NEW PARTNER: THE CENTRE FOR CONTEXTUAL MINISTRY (CCM)}

\section{The story of a new dream}

In 1988 Prof. Nel accepted a position in the Department of Biblical Studies at the then Vista University. Some 6000 day school teachers of Biblical Studies were registered with the Department for either the certificate or the diploma programme. The experience was a turning point in his life. As an externa marker of matric papers in the same year, he realised that if the teachers and matriculants had had good pastors, they might have been able to excel in their studies. The lack of understanding and factual knowledge of the Bible appalled him.

In 1989, Vista University management was asked whether the University could offer further training for South African pastors in the same way that Vista offered such training for day school teachers. Though positively received, such a venture was thought to be impossible, as it would have taken the form of unsubsidised community service.

\section{Research grants}

Vista University management, however, awarded Prof. Nel a research grant to determine whether there was a need for training among pastors in a number of mainline and independent churches in South Africa. Two assessments were accordingly undertaken, one in 1989 and one in 1991. Both assessments proved beyond any doubt that there was a great need for training among both untrained and trained pastors. The outcome of the research was published in 1995 (Nel 1995:74-94). Of the participants in the study, $84 \%$ expressed a strong need for continuing training. The following top five ministry needs could be seen to have changed only slightly in order of prioritisation from 1989 to 1991

\section{9}

1. Communication: Evangelism

2. Youth ministry and Christian education

3. Communication: General, as in preaching

4. Pastoral care

5. Building up of a local church

\section{1}

1. Youth ministry and Christian education

2. Communication: General, as in preaching

3. Building up of a local church

4. Communication: Evangelism

5. Pastoral care

A more detailed analysis has since shown that pastors with a Grade 12 level of education expressed a greater need for continuing training than did those without a Grade 12 level of education, and without formal theological training. Pastors who were less than five years in the ministry also expressed a greater need for continuing training (see Nel 1995:89-91).

\section{Two positive decisions}

The University Management Committee of Vista University was positive about the report that was submitted after the final outcomes of the two empirical need assessments. They, in principle, approved the establishment of a unit that was dedicated to meeting such needs. On 9 November 1990, the Vice-Rector for Administration wrote to Prof. Nel: 'The University Management Committee suggests that you postpone the establishment of the Unit till you have completed your upcoming sabbatical.' One of the provisions was that the necessary funding should be accessed to run the programme. Prof. Nel spent much of his sabbatical in the United States, where he made the required contacts, built up relationships, and raised sufficient funds to enable him to establish such a strategic missionary training programme. In his report on this exercise, which he submitted to the University Management Committee in November 1992, he asked the Committee to approve the establishment of the Unit, for which he proposed the name 'Division for Contextual Ministry'.

The mission, as stated in the first official request, was given as follows:

The mission of the Centre for Contextual Ministry is to train and equip Christian leaders who are in full-or part-time ministry to minister effectively to the membership of local churches in order to prepare Christians in all walks of life to make a difference to the coming of the Kingdom of God in their context, and in the South African society as a whole.

The goals of the Centre for Contextual Ministry include the following:

Ongoing and further theological in-service training of pastors and key leaders from any denomination in the understanding and use of the Bible and ministry skills that are contextually relevant to the communication of the Gospel of Jesus Christ;

Research into the development of contextual ministries with the aim of building up and edifying the local church in the South African community as a whole.

(CCM n.d.)

Vista University approved the establishment of the Division for Contextual Ministry on 23 November 1992. Prof. Nel was seconded to the Division as Head of the Division. The University paid the salary of a senior lecturer, with the difference in salary between that for the position and that for his position as a professor having to be sponsored from external sources. The University also established an Advisory Board, for which they approved a constitution. The Board was chaired by the ViceRector: Academic Affairs and, later, by the Principal of the Campus for Further Training.

\section{The first steps}

The Division's first four courses were offered in 1993. The courses, which were developed to meet the needs expressed by the pastors who had participated in the needs assessment, consisted of the following:

- Communication of the Gospel: Preaching; Youth Ministry; Building up the Local Church; and Pastoral Care (Vista University 1993). 
The courses were developed in cooperation with scholars in the relevant fields. Several other courses and seminars, such as those relating to trauma counselling and a workshop for pastors suffering from burnout, came to be offered at a later stage.

\section{Unforeseen, but not unexpected}

During the first few years it became obvious that, when learning takes place, people want to continue with academic studies. Prof. Nel referred such pastors and students to the Faculty of Theology at UP. Several such applicants obtained permission to enrol for an Honours degree, after the Faculty had evaluated the courses that they had already completed and had checked to see that other requirements had been fulfilled. Such an informal 'arrangement' was formalised in 1999, in an agreement entered into between UP and Vista University. Pastors could be accepted for a course-work Master's in Practical Theology on their successful completion of the two-year courses offered by the Division for Contextual Ministry at Vista University. Since then, many pastors and students have accepted such an opportunity to study towards their Master's degrees, in terms of the agreement between Vista University and UP. The agreement states:

\section{Article 5}

The parties undertake to work progressively towards a complete take-over of the DCM by UPFT while honouring the mission of DCM and continuing to assist students of the DCM in gaining access to formal academic study in the field of Theology.

(Agreement between UP and Vista University)

One anecdote recalls the benefits of such an agreement for those who have not had the benefit of access to tertiary education. The person concerned registered for the Advanced Course in Building up the Local Church, for which the entry requirements are a matric, plus at least a two-year post-matric diploma. When Prof. Nel explained what he needed to do in order to qualify for the Master's programme, he wondered whether he might be able to fulfil such requirements. Prof. Nel explained the degree requirements, for which he needed to have passed matric with university exemption. Disappointed, he accepted the explanation and finished his course with good results. He then registered for a second advanced course, which was in Pastoral Care. After successfully completing the course, he then applied for admission to the Honours degree programme in Pastoral Care, conducted by the Department for Practical Theology at UP. After being accepted for the advanced degree, he eventually finished his Master's and graduated with a $\mathrm{PhD}$ degree in Practical Theology from the same Department in April 2009.

\section{An end and a new beginning}

In 2000, rumours of the national plan to restructure tertiary education in South Africa were already spreading. The plan would, inevitably, affect Vista University, which was the youngest university in the country, leading to its unbundling. The campus for Further Training was supposed to be intended for relocation to the University of South Africa. By then, the aforementioned agreement concerning the possibilities for the Master's degree was working well. Moving to Unisa would mean that negotiations would have to start from the beginning again.

After consulting with the Dean of the Faculty for Theology (entailing discussions with Prof. W.S. Prinsloo in 1996, and later with Profs C.J. Wethmar and C.J.A. Vos), an agreement was drawn up and signed in August 2001. The agreement made provision for the relocation of the Division, with the full retention of its mission and the available funds, to UP.

\section{The dawn of a new day and a new name}

The Division for Contextual Ministry was relocated to the Theology Building of UP on 1 January 2002. UP approved both a new Constitution and a new name for the Division: The Centre for Contextual Ministry. Since then, the Centre has functioned as a centre of the Faculty of Theology. The courses planned for 2002 continued as planned, with most of them being offered in the Theology Building.

The Advisory Board, which was set up in terms of the Constitution, meets annually and is chaired by the Dean and the Director of the Centre, alternatively. As occurred at Vista University, the annual reports of the Director are approved by the Advisory Board.

The Budget of the Centre is also set and approved by the Advisory Board. The budget of about one million Rand is raised annually by means of sponsorships, as well as by individuals and by congregations. For seven years after 1999, Princeton Theological Seminary was the main sponsor, funding the Centre to the tune of USD30 000 per year, until 2008. New sponsors have since been found, and new relationships are currently in the process of being developed.

With the relocation of the Centre and its programme, it became part of Continuing Education at UP (CE@UP). The handling of all continuing education by the company benefits the functioning of the Centre, as it provides the latter with a support system. All accreditation and certification is performed by CE@UP, in accordance with the rules for continuing education, under the guidance and supervision of UP (see CE@UP n.d.).

\section{Exciting developments}

The Advisory Committee soon realised that offering the basic courses in Pretoria alone would not best serve the main purpose of the Centre. The many untrained, or insufficiently trained, individuals in ministry in the rural areas, and even in other urban settings, could not attend training in Pretoria. Many of the students are not in full-time ministry, and, even if they could afford the travelling expenses, getting leave to attend the training would often be problematic. Since 2000, the management of the Centre has already allowed pastors, who have passed the advanced courses with a good grade and who have the potential to teach, to teach the corresponding basic course in their own context. Soweto was the first venue approved for this. Pastor Phillip Dungulu has started to teach two basic courses, and Pastor Manyage has started to teach the Basic Course in Preaching.

The programme has developed in a well-coordinated way, though it is fairly spontaneous. Rev. Gawie Coetzee was the first to register for the advanced course in order that he might qualify to teach the corresponding course at a decentralised venue. He is currently teaching two of the basic courses at about five different venues each year. In the same way, both Dr Hannes Knoetze and the Rev. Arthur Pringle have started to become involved with the programme.

In 2007, the Advisory Committee embarked on a more formal way of decentralising the basic courses. Dr Hannes van der Walt, who had assisted on a part-time basis with administration since 2006, was appointed for 25 hours per week. He has been commissioned with developing a business plan for each decentralised programme, in order to encourage the enrolment of students, and in order to develop a broader financial support base for the Centre (CCM 2007). He is currently involved in seven such projects, while another, in Rustenburg, is already operational.

\section{CONTINUING EDUCATION PROGRAMMES FOR 2009 AND BEYOND}

\section{Courses, seminars and workshops}

In total, the two centres offer 20 advanced courses and seven seminars and workshops in Afrikaans (see the two websites: www.ccm.up.ac.za and www.excelsus.org). The CCM also offers nine advanced courses, eight basic courses and seven seminars and workshops in English. The student body that is catered for 
by such opportunities is diverse. Pastors and other leaders come from almost all the denominations and other more independent religious communities throughout the country. About 250 pastors attend such courses annually. It is hoped that another 200 DRC pastors will be able to participate in the Continuing Education Programme.

\section{Third-party agreements}

In 1994, the first request for the accreditation of an existing basic course offered by another institution was received. Leadership Focus offers a three-year correspondence and contact teaching course for Sunday school teachers. A local Presbyterian church on the East Rand has also started to offer a one-year course in Christian Lay Counselling.

In 1999, the Nehemia Bible Institute approached the then Division for Contextual Ministry with a request for Vista University to consider accrediting its three-year course in Basic Theology. First the Advisory Committee, and then the University Management Committee at Vista University approved the request. When the Centre relocated to UP, the accreditation of such programmes was re-evaluated by the CE@UP, and eventually approved by the deputy vice-principal for Administration. Since 2002, the two-year correspondence courses of the Hugenote Bible Institute and the one-year course offered by Urban Ministries in Pretoria have been accepted and approved in the same way. All such courses are on the basic level.

\section{Annual programme}

The total number of weeks of courses conducted in 2009 was close to 90 . Usually, such contact weeks run over four days, from a Monday to a Thursday. Short courses are offered over three days, and run from a Tuesday to a Thursday. An Afrikaans and English booklet containing all the course information, including a brief outlay of the content, dates and cost of such courses, is published annually. The booklets are mailed to some 2000 Afrikaans-speaking pastors and some 4000 English speaking leaders, after the more than 1400 alumni have received their booklets.

\section{CONCLUSION}

Continuing education consists of lifelong learning. Many who are involved in continuing education find that life is a journey. Living and enjoying the journey have everything to do with staying well informed and participating skilfully in whatever calling one has to fulfil. In the case of pastors, such fulfilment also concerns faithfulness to a calling and a respect for the people of God whom we serve in ministry. In this calling and ministry one never settles for less than God's best. Local congregations, just as with all other walks of life that are served by others, deserve the best. Pastors and other Christian leaders have to be well equipped. We are in need of leaders who are motivated by, and committed to, their calling and the people whom they serve. Leaders who are academically well trained and who are capable of reflective thinking are capable of making theologically informed choices in the ministry.

Nevertheless, some uncertainty and resistance from pastors to continuing ministerial development does exist (see Ward 2005:153-160, and her reference to 'good and bad resistance' in the process of 'learning to learn'). Such opposition adds to the challenges resulting from the lack of human resources, the financial constraints that are imposed upon congregations, and the over-taxed schedules of busy pastors. Lord expressed the problematic nature of the task that lies ahead well:

What is our real intention - maintenance or transformation? What is now required of providers? Surely it is nothing less than reframing our role. We step out on a journey, but we do so without the aid of a well-documented map. At best, we have a compass composed of our basic values about:

- adult learning and the teaching/learning process

- the learners
- $\quad$ all the stakeholders, personal, institutional, or societal

- democratization of the planning process

- programs that result in transformation for persons, churches, and society.

(Lord 2000:62)

\section{REFERENCES}

The Archbishops' Council, 2001, Mind the gap: Integrated continuing ministerial education for the church's ministers, The Council, London.

Aspin, D.N. (ed.), 2007, Philosophical perspectives on lifelong learning, Springer, Dordrecht.

British Journal of Theological Education, 1992, 5(1).

Bullock, A.R. \& Bruesehoff, R.J., 2000, Clergy renewal: The Alban guide to sabbatical planning, Alban Institute, Bethesda.

Bybel-Media, 2007, Bedieningsvreugde vir predikante met die A-Z beleid vir predikante van die NG Kerk, interactive DVD.

Centre for Contextual Ministry (CCM) n.d., viewed n.d., from www.ccm.up.ac.za.

Centre for Contextual Ministry (CCM), 2007, Unpublished minutes, 2 November 2007.

Continuing Education at the University of Pretoria (CE@UP), n.d., viewed n.d., from www.ce@up.ac.za.

Council for Lutheran Theological Education, 1982, Guide to continuing education programs for professional leaders, Philadelphia.

Excelsus, n.d., viewed n.d., from www.excelsus.org.

Gamble, C., 1960, Continuing theological education of the American minister, Union Theological Seminary, Richmond.

Glasse, J., 1968, Profession: Minister, Abingdon, Nashville.

Journal of Adult Theological Education (JATE), Equinox, London.

Kotze, C.S., 1988, 'Fakulteit en Universiteit', in P.B. van der Watt (ed.), Deo Gloria! Teologiese Fakulteit, 1938-1988, pp. 59-81, NGKB, Pretoria.

Ledl, A., 2007, Lebenslangen Lernen als Reformprogrammen: Aufbrüche in der Reformationszeit durch Hieronymus Weller und Christoph Fischer, Paideia, Jena.

Lord, W., 2000, 'Providers: Then and now', in R.E. Reber \& D.B. Roberts (eds.), A Lifelong Call to Learn: Approaches to Continuing Education for Church Leaders, pp. 52-64, Abingdon, Nashville.

Nederduitse Gereformeerde Kerk (NGK), 1978, Handelinge van die Algemene Sinode, Bloemfontein.

Nederduitse Gereformeerde Kerk (NGK), 2002, Handelinge van die Algemene Sinode, Pretoria.

Nederduitse Gereformeerde Kerk (NGK), 2004a, Handelinge van die Algemene Sinode, Hartenbos.

Nederduitse Gereformeerde Kerk (NGK), 2004b, Notule van die Kuratorium, 11 November 2004, 6.6.

Nederduitse Gereformeerde Kerk (NGK), 2007, Handelinge van die Algemene Sinode, Kempton Park.

Nel, M., 1995, 'Voortgesette teologiese opleiding en die opleidingsbehoeftes van pastors', Praktiese Teologie in SA 10(2), 74-94.

Nel, M., 2001, Ek is die verskil: Die invloed van persoonlikheid in die prediking, CLF, Bloemfontein.

Nel, M., 2002, 'Predikante-opleiding: Roeping, keuring en legitimering', Verbum et Ecclesia 23(1), 151-67.

Nel, M., 2004, 'Publieke pastorale leiers 1: Roeping, werwing, keuring, opleiding, ordening', Verbum et Ecclesia 25(2), 584618.

Nel, M., 2005, 'Publieke pastorale leiers 2: Roeping, werwing, keuring, opleiding, ordening', Verbum et Ecclesia 26(2), 459506.

Oehler, C.H., 2000, 'Welcoming the whole person', in R.E. Reber \& D.B. Roberts (eds.), A Lifelong Call to Learn: Approaches to Continuing Education for Church Leaders, pp. 237-46, Abingdon, Nashville.

Presbyterian Church USA, 1995, On being faithful, Higher Education Program Team, Louisville.

Reber, R.E. \& Roberts, D.B. (eds.), 2000, A lifelong call to learn Approaches to continuing education for church leaders, Abingdon, Nashville. 
Rouch, M., 1974, Competent ministry: A guide to effective continuing education, Abingdon, Nashville.

Rouch, M., 2000, 'From yesterday to today in continuing education', in R.E. Reber \& D.B. Roberts (eds.), A Lifelong Call to Learn: Approaches to Continuing Education for Church Leaders, pp. 19-38, Abingdon, Nashville.

Sevier, M.B., 2002, Journeying toward renewal: A spiritual companion for pastoral sabbatical, Alban Institute, Bethesda.

Trost, T.L., 1962, Continuing theological education for Protestant clergymen, University Microfilms, Ann Harbor.

Van der Watt, P.B., 1988, Deo Gloria! Teologiese Fakulteit, 19381988, NGKB, Pretoria.
Vista University, 1993. Prospectus: Division for Contextual Ministry, Vista University Press, Pretoria.

Vosloo, W. n.d., unpublished personal 'Dagboek van Wil Vosloo'.

Wagener, B.R., 1982, Pastor orientation to vocation through continuing education, University Microfilms, Ann Harbor.

Ward, F., 2005, Lifelong learning: Theological education and supervision, SCM, London.

Withnall, A., 1986, The Christian churches and adult education: Review of research and practice in adult education, vol. XIII, National Institute of Adult Continuing Education, Leicester. 